\title{
Recerca geològica i mineralògica per la comarca de I’Alt Palància: Segorbe/Sogorb a Navajas, Jérica/Xérica, Caudiel, a Higueras/Figueres i a Pavías / Pavíes
}

Josep Maria Mata-Perelló

Joaquim Sanz Balagué

Jaume Vilaltella Farràs

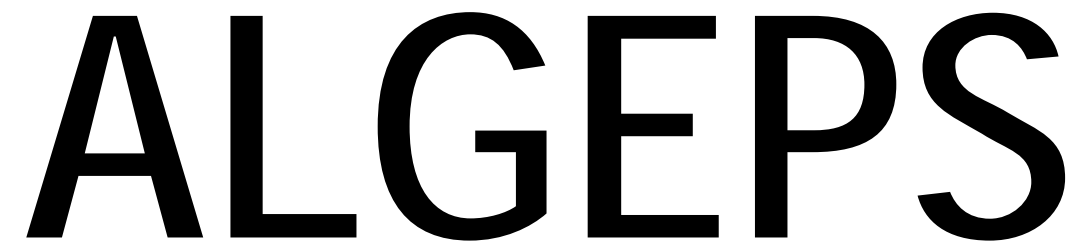

\section{REVISTA DE GEOLOGIA}

\section{n. 4}

DESEMBRE 2014 


\title{
RECERCA GEOLÒGICA I MINERALÒGICA PER LA COMARCA DE L'ALT PALÀNCIA: SEGORBE/SOGORB A NAVAJAS, JÉRICA/XÉRICA, CAUDIEL, A HIGUERAS/FIGUERES I A PAVÍASIPAVÍES
}

\author{
Josep Maria Mata-Perelló \\ Museu de geologia Valentí Masachs, Escola Politècnica Superior d'Enginyeria de Manresa \\ (EPSEM), Universitat Politècnica de Catalunya · BarcelonaTech (UPC), 08272 Manresa, Spain
}

\section{Joaquim Sanz Balagué}

Departament d'Enginyeria Minera i Recursos Naturals (EMRN), Escola Politècnica Superior d'Enginyeria de Manresa (EPSEM), Universitat Politècnica de Catalunya · BarcelonaTech (UPC), 08272 Manresa, Spain

Jaume Vilaltella Farràs

Paraules clau: Patrimoni geològic i miner; Sistema ibèric; País Valencià

\section{Resum}

Itinerari realitzat el dia 8 de desembre del 2013. Aquest itinerari geològic $i$ mineralògic, discorrerà íntegrament dintre del Sistema Ibèric. Així, en la major part dels trajectes anirem trobant afloraments dels diferents materials triàsics. Tot i això, també trobarem afloraments dels materials del Juràssic i del Cretàcic. Ocasionalment, cap a la fi del recorregut. També trobarem afloraments dels materials paleozoics del Carbonífer.

Per d'altra banda, cal dir que tot $i$ així, malgrat trobar-se força lluny de la denominada Zona d'Enllaç, aquesta zona encara es troba afectada per fractures de direcció catalana. Efectivament, al llarg del recorregut, anirem trobant diverses estructures d'arrumbament clarament català, de direccions predominants NE - SW i NNE - SSW. Aquestes direccions són perpendiculars amb les ibèriques (NW - SE).

Finalment, cal dir que aquest itinerari transitarà per una sola comarca del País Valencià, concretament per la de l'Alt Palància. Així s'iniciarà a la capital comarcal, a Segorbe / Sogorb per a finalitzar al terme de Pavías / Pavíes, molt prop de les comarques de la Plana Baixa i de I'Alt Millars, també valencianes. 


\section{Objectius fonamentals}

Dintre d'aquest itinerari, ens fixarem els següents objectius, d'acord amb el sentit de la marxa:

1.- Estudi i observació dels materials paleozoics (del Carbonífer) i dels mesozoics (del Triàsic, quasi exclusivament), que constitueixen el Sistema Ibèric, per on discorrerà la totalitat del recorregut de l'itinerari, entre les poblacions de Segorbe i Pavíes / Pavíes. Tanmateix, a diferents indrets del recorregut, trobarem afloraments de materials carbonatats del Juràssic.

2.- Observació de les estructures del Sistema Ibèric, dintre dels Relleus Triàsics de Sagunt, per on discorrerà tot aquest itinerari. En aquest recorregut es veuran diverses fractures de clara direcció catalana (NE - SW i NNE - SSW), entrecreuant-se amb altres de direcció ibèrica (NW $-\mathrm{SE})$.

3.- Estudi de diverses mineralitzacions situades entre els materials triàsics del Sistema Ibèric. Entre aquestes, farem esment de les Mineralitzacions cupríferes associades a "red-beds", situades a Pavías / Pavíes situades entre els materials triàsics del Buntsandsteim.

4.- Observació d'algunes explotacions realitzades a "cel obert" o subterrànies, antigues o actuals, com les antigues explotacions de minerals de coure, situades al terme de Pavías I Pavíes, entre altres indrets

5.- Observació de l'impacte produït per les explotacions anteriors sobre el medi natural, i si s'escau de les restauracions dutes a terme per a reduir aquest impacte.

6.- Observació dels diferents indrets relacionats amb el nostre Patrimoni Geològic que anirem trobant al llarg del recorregut de l'itinerari, i en especial dels que puguin ésser catalogats com a LIG (Llocs d'Interès Geològic, com el Salt de la Novia, de Navajas, tot i el seu caràcter antròpic).

7.- Observació dels diferents indrets relacionats amb el nostre Patrimoni Miner que anirem trobant al llarg del recorregut de l'itinerari, i en especial dels que puguin ésser catalogats com a LIPM (Lloc d’Interès del Patrimoni Miner)

\section{Antecedents}

No coneixem l'existència de cap antecedent bibliogràfics relatiu al conjunt d'aquest itinerari. Tot i així, hi ha alguns antecedents parcials nostres: MATA-PERELLÓ (2003, 2004 i 2010). Així com de MATA - PERELLÓ i VILALTELLA FARRÀS (2013).

Pel que fa a l'estudi de les mineralitzacions situades al llarg del recorregut, farem un especial esment del treball de MATA-PERELLÓ (1984), relatiu a les mineralitzacions que s'estenen per les comarques per les quals discorre el recorregut de l'itinerari.

Pel que fa a l'estructura geològica dels indrets pels quals discorrerà el recorregut de l'itinerari, farem esment de dos treballs generals, relatius al conjunt dels Països Catalans: GUIMERÀ et altri (1992), i RIBA et altri (1976). Igualment, cal fer esment dels fulls del Mapa Geológico de España corresponents a la zona: IGME (1074a i b).

També, pel que fa al Patrimoni Miner, farem referencia d'un treball nostre recent: MATAPERELLÓ et altri (2012).

Tots aquests treballs esmentats, figuraran per ordre alfabètic a l'apartat dedicat a la bibliografia. 


\section{Recorregut de l'itinerari}

El recorregut d'aquest itinerari comença a la comarca de I'Alt Palància, dintre del terme de Segorbe / Sogorb, on es farà la primera parada del recorregut del present itinerari. A continuació, el recorregut es dirigirà cap el Nord, seguint la carretera nacional N - 234 (en el seu recorregut antic), anant cap a la població de Navajas, seguint també la carretera CV 2160. En aquesta darrera població es realitzarà una nova aturada, a la bora del riu Palància.

Tot seguit, des de Navajas caldrà anar cap a l'Ermita de Nuestra Señora de la Esperanza (seguint la carretera CV - 216). Així, retornarem a la ruta nacional $\mathrm{N}-234$, per la qual hem circulat a l'inici del recorregut. Des d'aquí arribarem a la població de Jérica / Xérica, per on farem una nova aturada a la bora del riu Palància.

Després, ens caldrà agafar la carretera CV - 195, la qual ens portarà cap a Caudiel. Poc després de sobrepassar aquest poble, ens caldrà agafar (per la dreta) la carretera CV - 203, la qual condueix cap a Higueras / Figueres. En aquest tram farem una nova aturada. Posteriorment, seguint la mateixa carretera, caldrà anar cap a Pavías / Pavíes, des d'on es seguirà breument cap a Torralba del Pinar. Tot i així, a poca distancia del primer poble esmentat en aquest paràgraf, es farà una nova aturada, la darrera d'aquest itinerari, just al límit entre I’Alt Palància i I' Alt Millars.

\section{Advertiments previs}

Com en altres recorreguts de recerca geològica i mineralògica ..., si es disposa del temps suficient, poden efectuar-se passant per totes les parades i filloles. En cas contrari, recomanem prescindir de les anomenades parades - condicionals.

També cal tenir en conte que una part del recorregut final de l'itinerari, es realitzarà per camins de terra, per la qual cosa caldrà prendre les degudes precaucions. Així, d'aquesta manera es circularà pels diferents camins d'accés a les mines de coure de Pavías / Pavíes.

Cal tenir, com sempre, una cura molt especial de respecte a la natura, al llarg de tot el recorregut de l'itinerari, i també fora d'ell.

\section{Descripció de l'ítinerari}

Com en altres itineraris, a continuació veurem una sèrie de "parades o estacions". En cada una d'elles es farà un breu comentari, ja sigui de caràcter geològic, geomorfològic 0 mineralògic, segons s'escaigui.

Per d'altra banda, darrera del nom de l'indret (o de la parada), situarem entre parèntesi el número del Mapa Topogràfic, a escala 1:50.000, on es troba l'indret de l'aturada. En aquesta ocasió, utilitzarem tres fulls de l'esmentat mapa topogràfic; concretament, el full 639 (o Full de Jérica), el 640 (dit ara d'Onda i anteriorment de Segorbe) i el 668 (o de Sagunt). Aquests fulls han estat publicats pel Instituto Geográfico y Catastral de España.

Així doncs, la relació general de les aturades que constitueixen aquest itinerari, d'acord amb el sentit de la marxa, és el següent:

\subsection{Parada 1 - Condicional. Argilera de Segorbe, (terme municipal de Segorbe, comarca de I’Alt Palància).(Full 668).}


El recorregut de l'itinerari, el començarem en aquest indret, situat al costat de la població de Segorbe / Sogorb. Molt prop de la carretera CV - 215, la qual condueix cap a Castellnovo. A menys de $1 \mathrm{Km}$ de la primera població, farem aquesta aturada.

En aquest recorregut, hem trobat afloraments de materials cenozoics neògens del Miocè. Aquests materials han estat explotats a diferents indrets propers a la capital comarcal,. Com el de la present aturada.

Així, en aquest indret, es fa clarament palesa una explotació d'aquets materials argilosos. (fotografia 1).

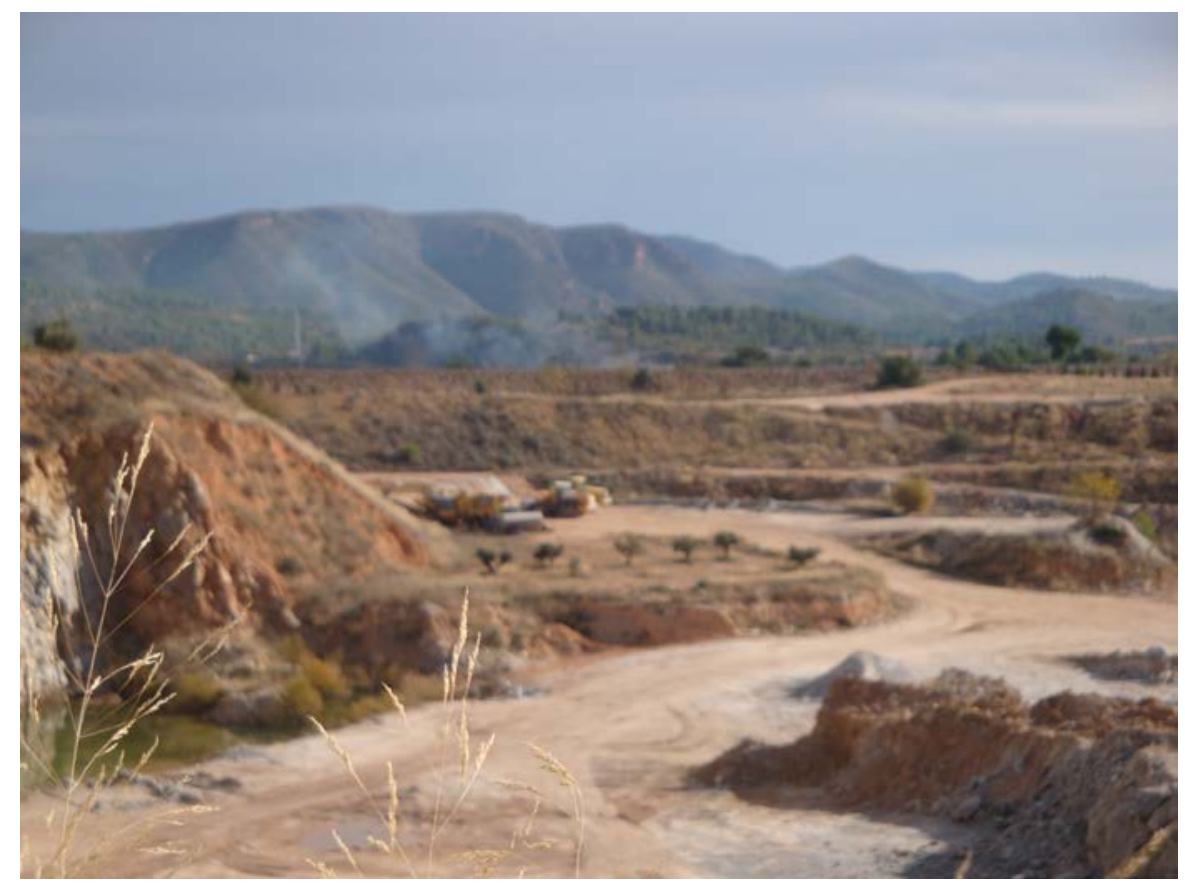

FOTOGRAFIA 1. Explotacions de les argiles del Miocè a Segorbe. Desembre del 2010.

\subsection{Parada 12. El salt de la novia, (terme municipal de Navajas, comarca de I'Alt Palància). (Full 640).}

Després de fer l'aturada anterior, cal anar cap a Segorbe / Sogorb. En arribar-hi, ens caldrà anar cap a la propera població de Navajas, seguint la carretera CV - 2160. En arribar-hi, baixarem cap a la vall del riu Palància, per on farem una propera aturada, a uns $4 \mathrm{Km}$ de la parada anteriorment realitzada.

En aquest recorregut, hem trobat afloraments dels materials miocènics que hem vist a l'aturada anterior. Tot i així, en baixar des de Navajas cap al riu Palància, haurem tornat a trobar afloraments dels materials carbonatats del Juràssic Inferior, del Liàsic, que són els materials que afloren a l'indret de l'aturada.

En aquest indret, el riu Palància ha obert un congost entre aquests materials carbonatats del Juràssic. A les boes d'aquest congost hi ha abundants surgències, amb formació de travertins. Tot i així, la més vistosa és la coneguda com a Salt de la Novia. En aquesta, I'aigua procedeix del sobreeiximent d'un canal (fotografies 2, 3 i 4). 


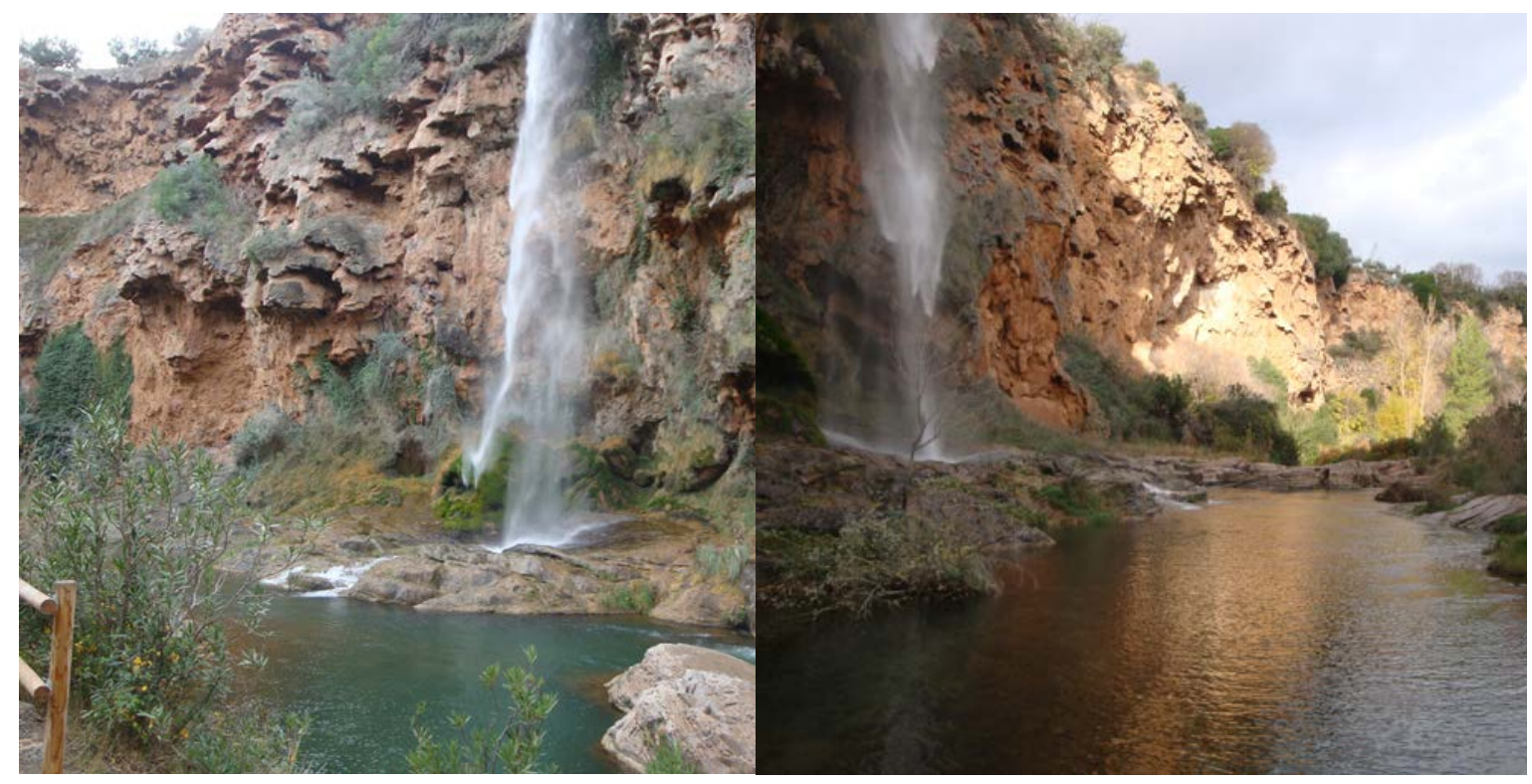

FOTOGRAFIES 2i 3. El Salt de la Novia. Navajas, riu Palància. Desembre 2011

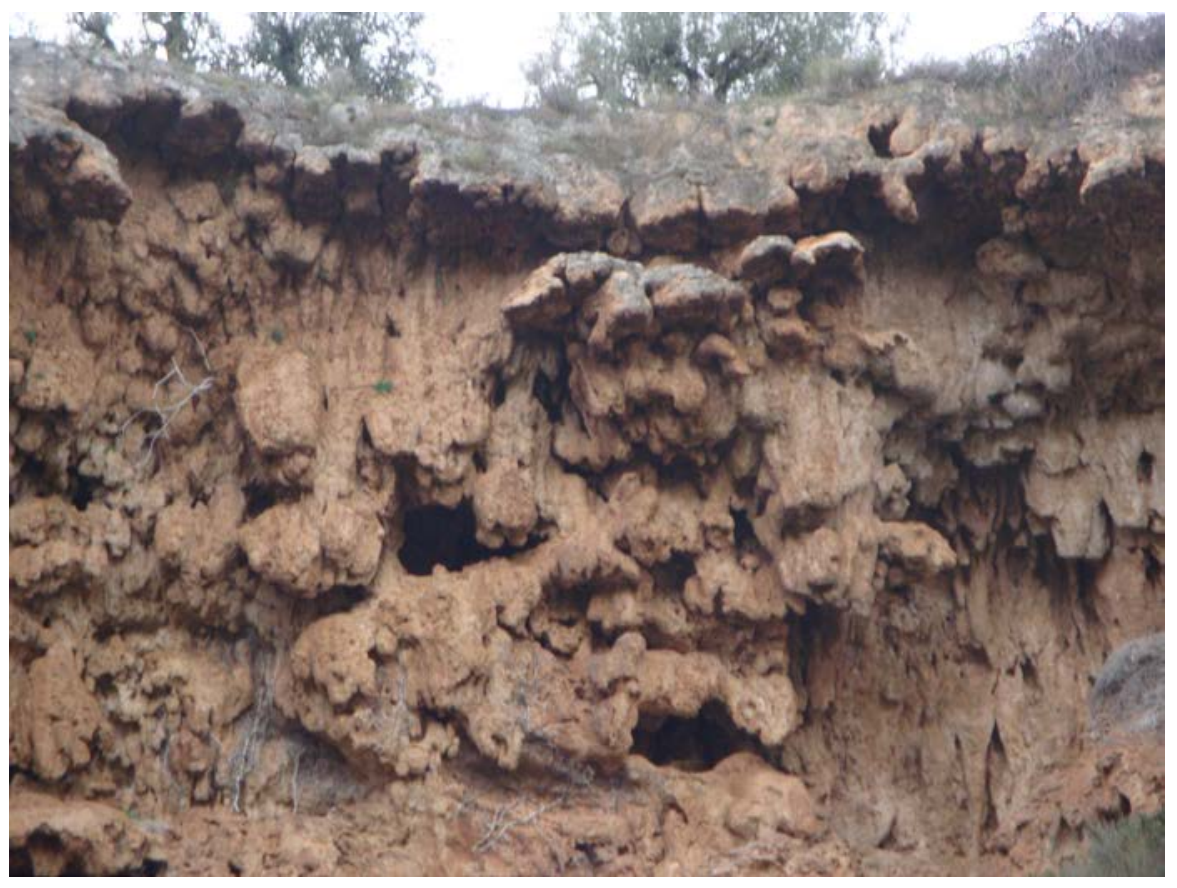

FOTOGRAFIA 4. Els travertins del riu Palància. Navajas. Desembre 2011 


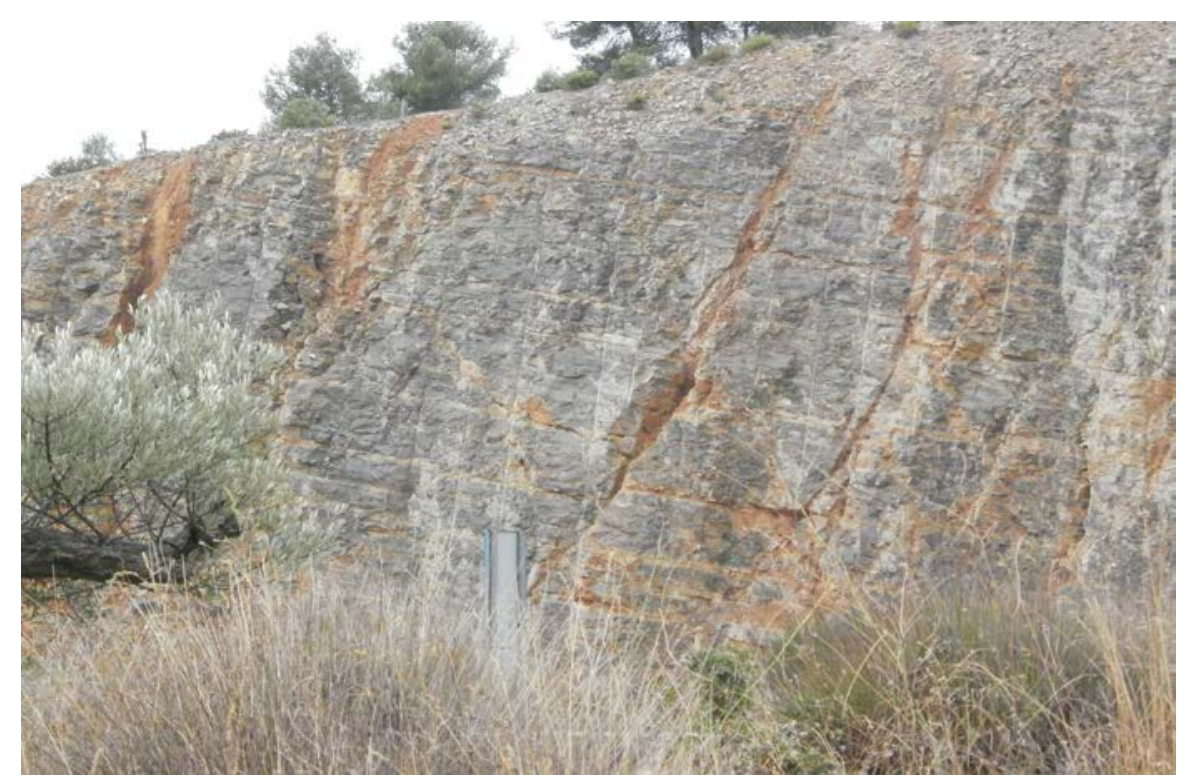

FOTOGRAFIA 5. Camp de fractures sobre les calcàries juràssiques, prop del Km 36 de la N - 234,. Novembre, 2013

\subsection{Parada 3. Carretera n - 234, Km 36, (terme municipal de Jérica I Xérica, comarca de l’Alt Palància). (Full 639).}

Després de realitzar la parada anterior, cal retornar cap al poble de Navajas. Tot seguit, ens caldrà anar cap a l' Ermita de Nuestra. Señora de la Esperanza (seguint la carretera CV - 216). Així, retornarem després a la carretera nacional N - 234, en el seu trajecte antic. Des d'aquí. Ens caldrà seguir per la carretera vella, anant cap a Jerica. En arribar al Km 36, farem una nova aturada. Així, des de la parada anterior, haurem recorregut uns $5 \mathrm{Km}$, aproximadament.

En aquest recorregut, hem anat trobant afloraments dels materials mesozoics, que en la seva major part pertanyen al Juràssic, Es tracta de materials eminentment carbonatats. Per d'altra banda, en aquest tram del recorregut (com al llarg de tot I'itinerari), estem plenament situats dintre del Sistema Ibèric.

En aquest indret, situat al costat de l'autovia, es fa palès un conjunt de fractures, ben visibles al marge occidental de l'esmentada autovia. Així, es veuen fractures de direcció ibèrica i tanmateix fractures de direcció "catalana". FOTOGRAFIA 5

\subsection{Parada 4. Meandre del riu Palància a Jérica, (terme municipal de Jérica $I$ Xérica, comarca de I’Alt Palància). (Full 639).}

Després de realitzar la parada anterior, cal continuar per la carretera $\mathrm{N}-234$, en el seu trajecte antic. Des d’aquí arribarem a la població de Jérica / Xérica, per on farem una nova aturada a la bora del riu Palància. Així, des de la parada anterior, haurem efectuat un recorregut de $4 \mathrm{Km}$.

En aquest recorregut, hem trobat afloraments dels materials esmentats a les aturades anteriors, els quals pertanyen al Triàsic i al Juràssic. Tanmateix, prop de Jérica, haurem trobat afloraments dels materials carbonatats del Cretàcic. 


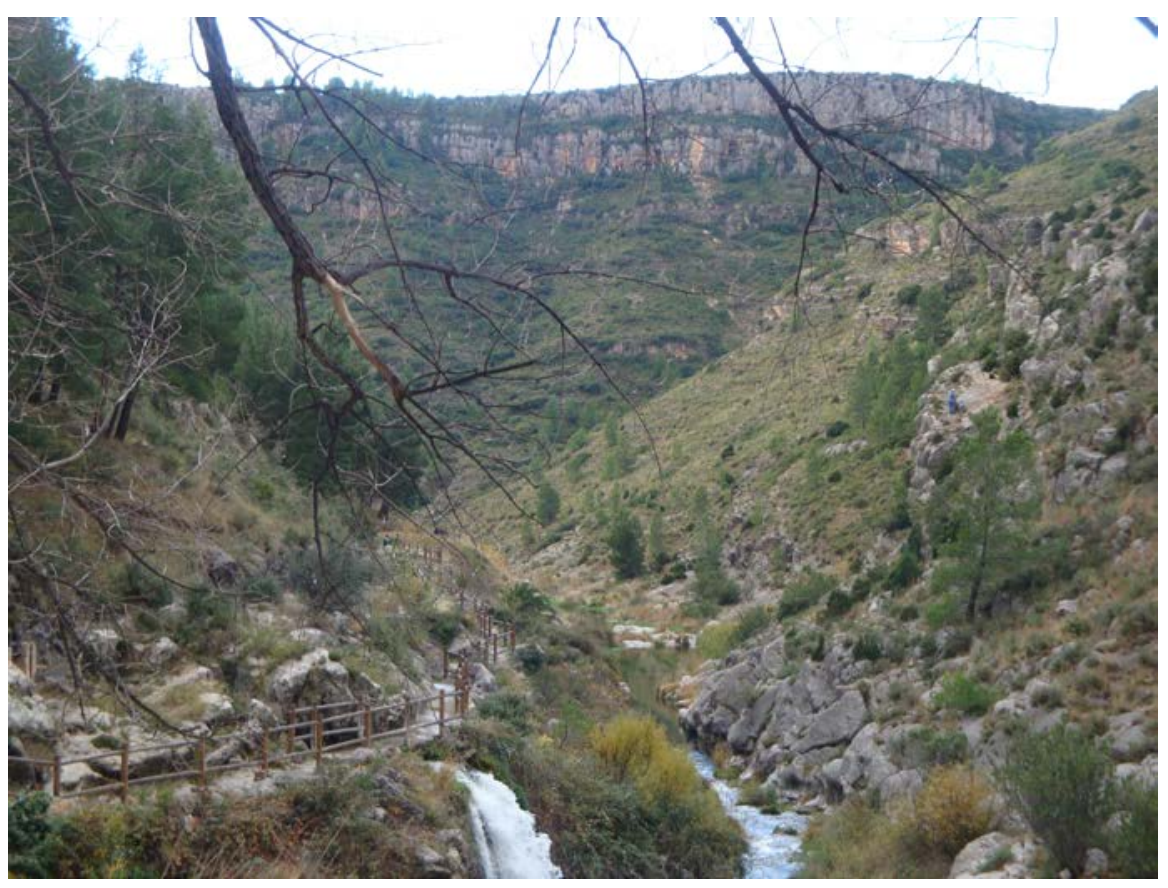

FOTOGRAFIA 6. Un aspecte del riu Palància al Congost de Jérica. Desembre 2011

El riu Palància en aquests indrets es troba encaixonat entre els nivells carbonats del Juràssic. I descriu un interessant meandre engorgat entre les calcàries juràssiques. (fotografies 6 i 7).

Aquests materials es troben força fracturats, en trobar-se afectats per la tectònica catalana (de direccions NE - SW i NNE - SSW) i per fractures ibèriques (de direccions predominants NW $\mathrm{SE}$, generalment perpendiculars a les anteriors).

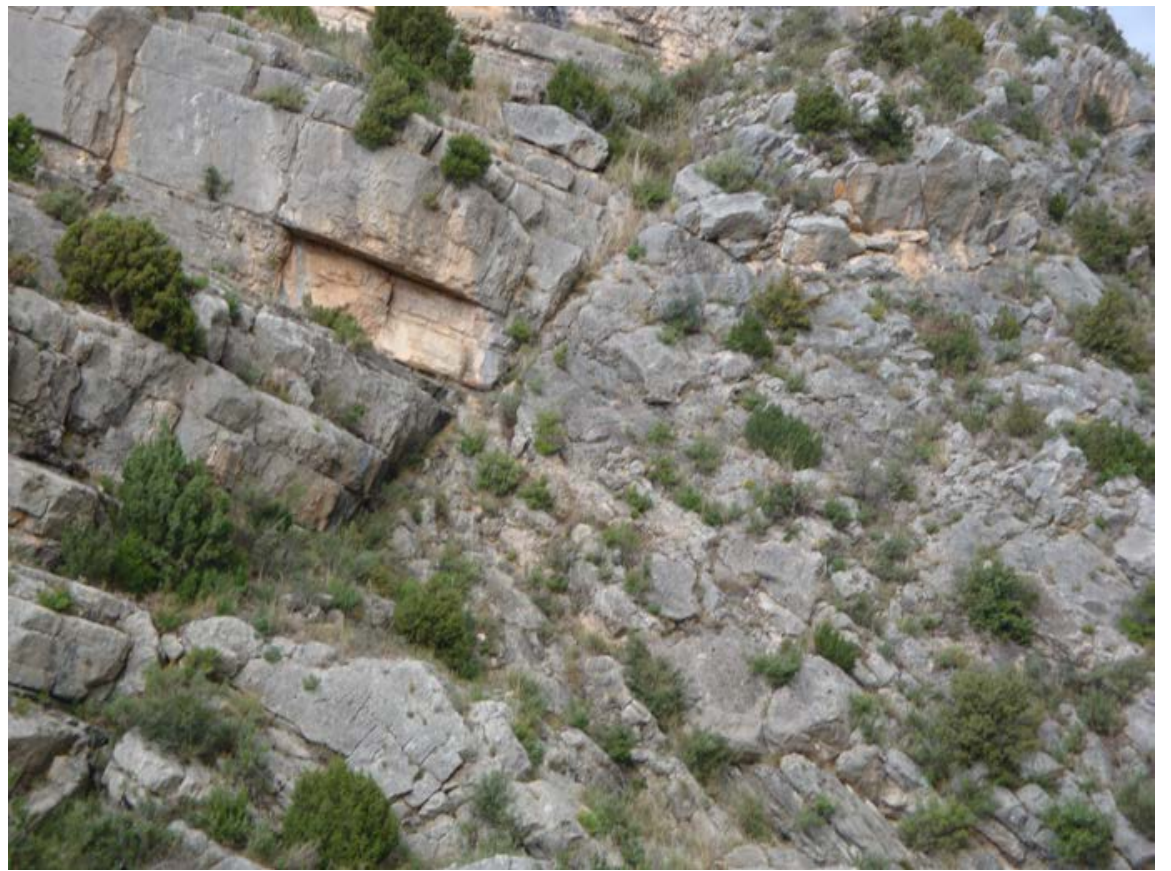

FOTOGRAFIA 7. Una fractura entre els materials juràssics al Congost de Jérica. Desembre 2011 


\subsection{Parada 5. Inici de la carretera de Caudiel a Higueras, (terme de Caudiel, comarca de l'Alt Palància). (Full 640).}

Després de realitzar la parada anterior, cal retornar al poble de Jérica / Xérica. Posteriorment, ens caldrà agafar la carretera CV - 195, la qual ens portarà cap a Caudiel. Poc després de sobrepassar aquest poble, ens caldrà agafar (per la dreta) la carretera CV - 203, la qual condueix cap a Higueras. Prop de l'inici d'aquesta carretera, farem una nova aturada, a uns 8 $\mathrm{Km}$ de I'anterior, aproximadament. Aquesta aturada la realitzarem per les proximitats del $\mathrm{Km}$ 26, de la carretera CV - 203.

En aquest recorregut, hem anat trobant afloraments dels materials mesozoics que formen part del Sistema Ibèric, on estem situats des de l'inici del present recorregut. Així, en aquest indret apareixen uns nivells de calcaries, gresos i calcolutítes liàsiques.

Tot i així. entre aquests materials es fan força palesos uns afloraments de toves volcàniques, de naturalesa bàsica. (fotografia 8).

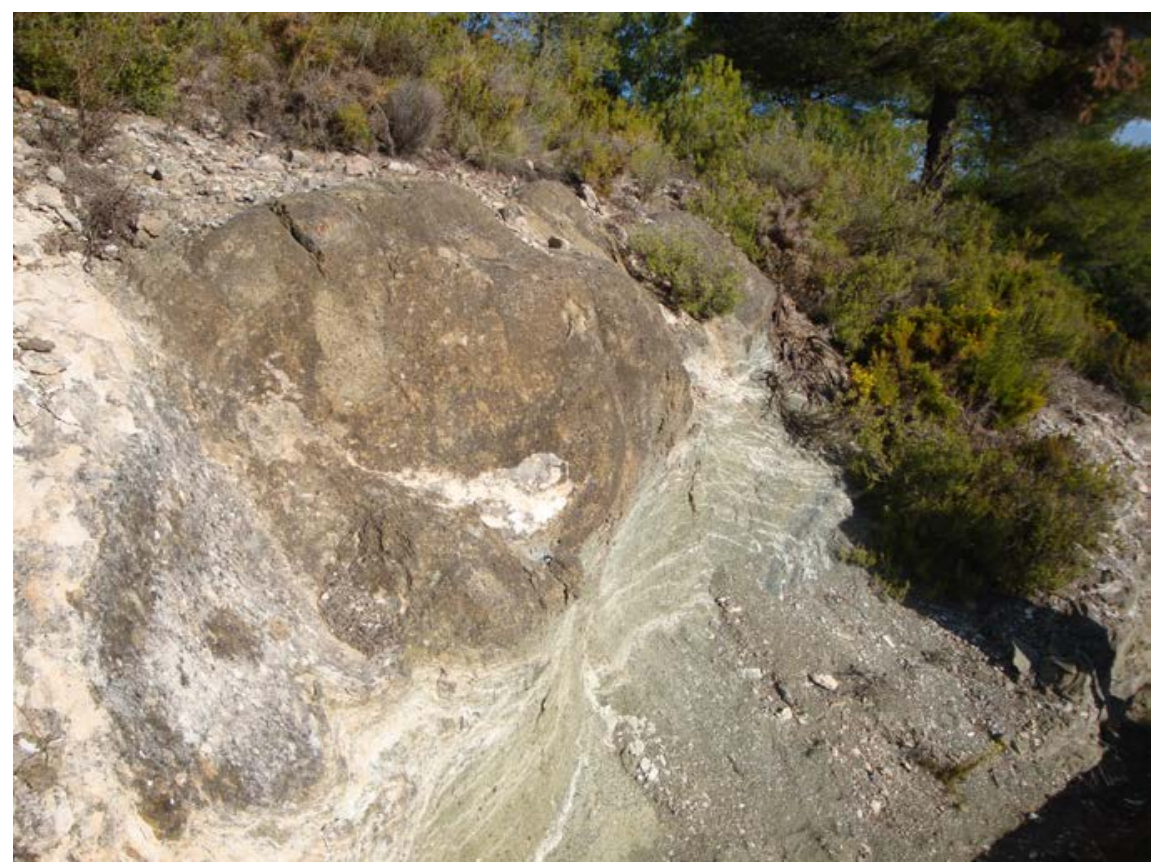

FOTOGRAFIA 8. Toves volcàniques, entre els materials liàsics, prop de Caudiel. Desembre 2011

\subsection{Parada 6 - condicional. Carretera de Caudiel a Higueras, $\mathrm{Km} \mathrm{22}$ '8, (terme de Higueras I Figueres, comarca de I’ Alt Palància). (Full 640).}

Després de realitzar la parada anterior, cal continuar per la carretera CV - 203, la qual es va condueix cap al poble de Higueras. En arribar a les immediacions del seu $\mathrm{Km} \mathrm{22}$ ' 8 , podem fer una nova aturada, si s'escau.

En aquest recorregut, hem continuat trobant afloraments dels materials esmentats a les aturades anteriors, fonamentalment del Juràssic i del Triàsic. Com als altres recorreguts, estem dintre del Sistema Ibèric. 
En aquest indret hi ha una fractura que afecte als materials mesozoics del Triàsic, que afloren en aquest lloc.

\subsection{Parada 7. Barranco de Pavias, (terme municipal de Pavías I Pavíes, comarca de I’Alt Palància). (Full 640).}

Després de realitzar la parada anterior, cal continuar per la carretera CV - 203, anant cap a Higueras. Posteriorment, ens caldrà continuar, per tal d'arribar a les immediacions de Pavias. Just en sobrepassar el barranc del nom del poble, farem una nova aturada, a uns $5 \mathrm{Km}$ de I'anteriorment realitzada.

En aquest recorregut, inicialment hem trobat els materials esmentats a les aturades anteriors, del Triàsic, fonamentalment. Tot i així, en arribar a Higueras (i fins aquest indret), hem començat a trobar afloraments dels materials paleozoics, que fonamentalment pertanyen al Paleozoic (probablement al Carbonífer). Així, haurem vist per arreu, afloraments de pissarres i de quarsites. Aquests són també els materials que apareixen a l'indret de la present aturada, molt prop del poble de Pavías (fotografia 9).

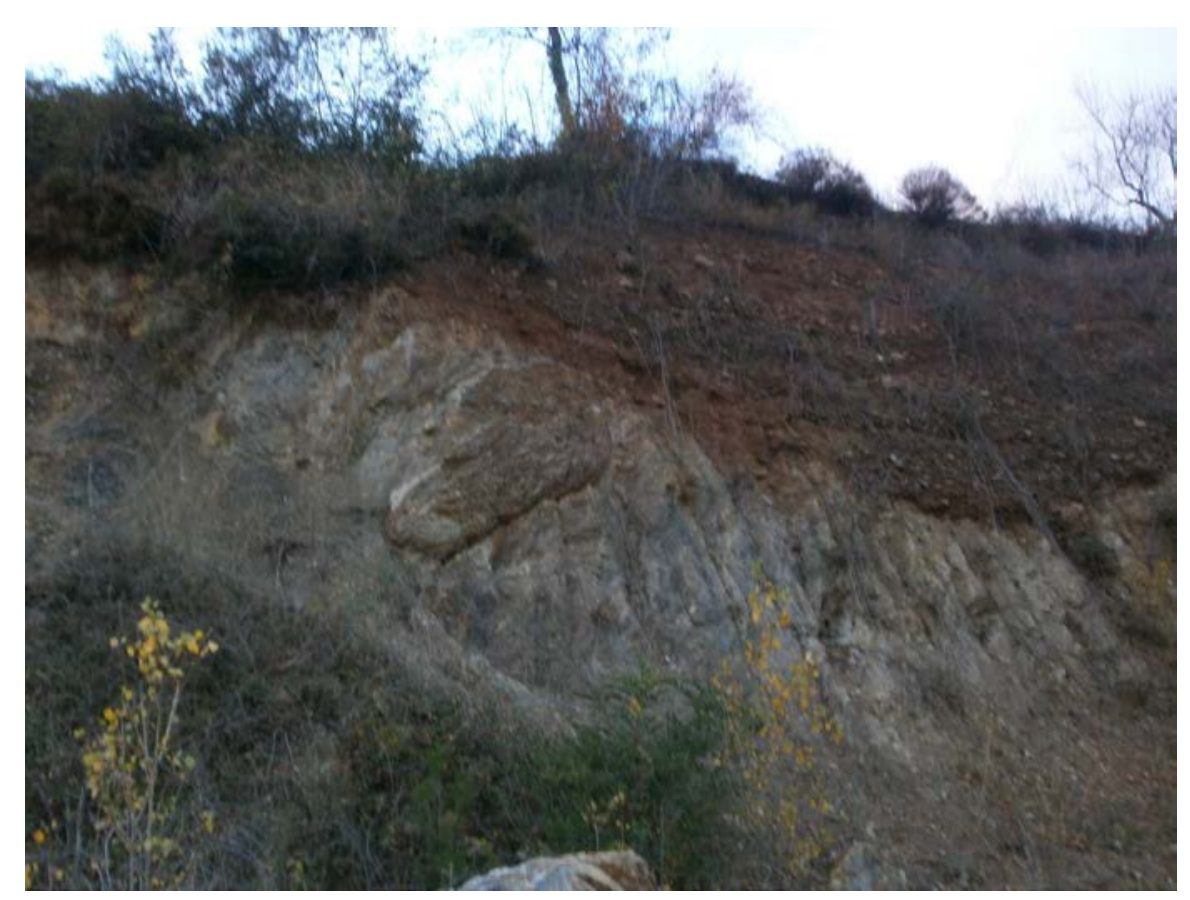

FOTOGRAFIA 9.Aflorament dels materials paleozoics al Barranc de Pavías, Novembre del 2013

Finalment, cal dir que en aquest indret hi ha hagut una antiga explotació dels materials paleozoics, per tal d'ésser emprats com a àrids. 


\subsection{Parada 8. Mines del Carrascal. Mines de coure de Pavías - 1, (terme municipal de Pavíes I Pavíes, comarca de l'Alt Palància. (Full 640).}

Després de realitzar la parada anterior, cal continuar per la carretera CV - 203, amb la finalitat d'arribar ara fins al poble de Pavías / Pavíes. En arribar-hi, ens caldrà seguir cap a llevant, anant cap a Torralba del Pinar, utilitzant la mateixa carretera. Tot i així, aviat es trobarà per l'esquerra un camí ample, en bones condicions, el qual es dirigeix cap el Nord, cap el Carrascal. Ens caldrà agafar-lo. Així, arribarem a les antigues Mines de coure de Pavías. En aquest indret farem la darrera aturada, a uns $7 \mathrm{Km}$ de I'anteriorment realitzada.

En aquest recorregut, hem trobat afloraments dels materials esmentats a les aturades anteriors; tot i que ara predominen els materials triàsics. Tot i així, en aquest recorregut, haurem passat per afloraments de materials paleozoics del Carbonífer, amb trams de pissarres i de quarsites. Tots aquests materials es troben intensament fracturats.

En arribar a l'indret de l'aturada, es fa palesa una interessant mineralització cuprífera associada a red-bed. Aquesta es troba entre els gresos del Buntsandstem, en contacte per falla amb els materials paleozoics. Entre els minerals presents es fan força pesos els carbonats, I'atzurita i la malaquita, que són els minerals més abundants d'aquest indici (fotografies10 i 11).

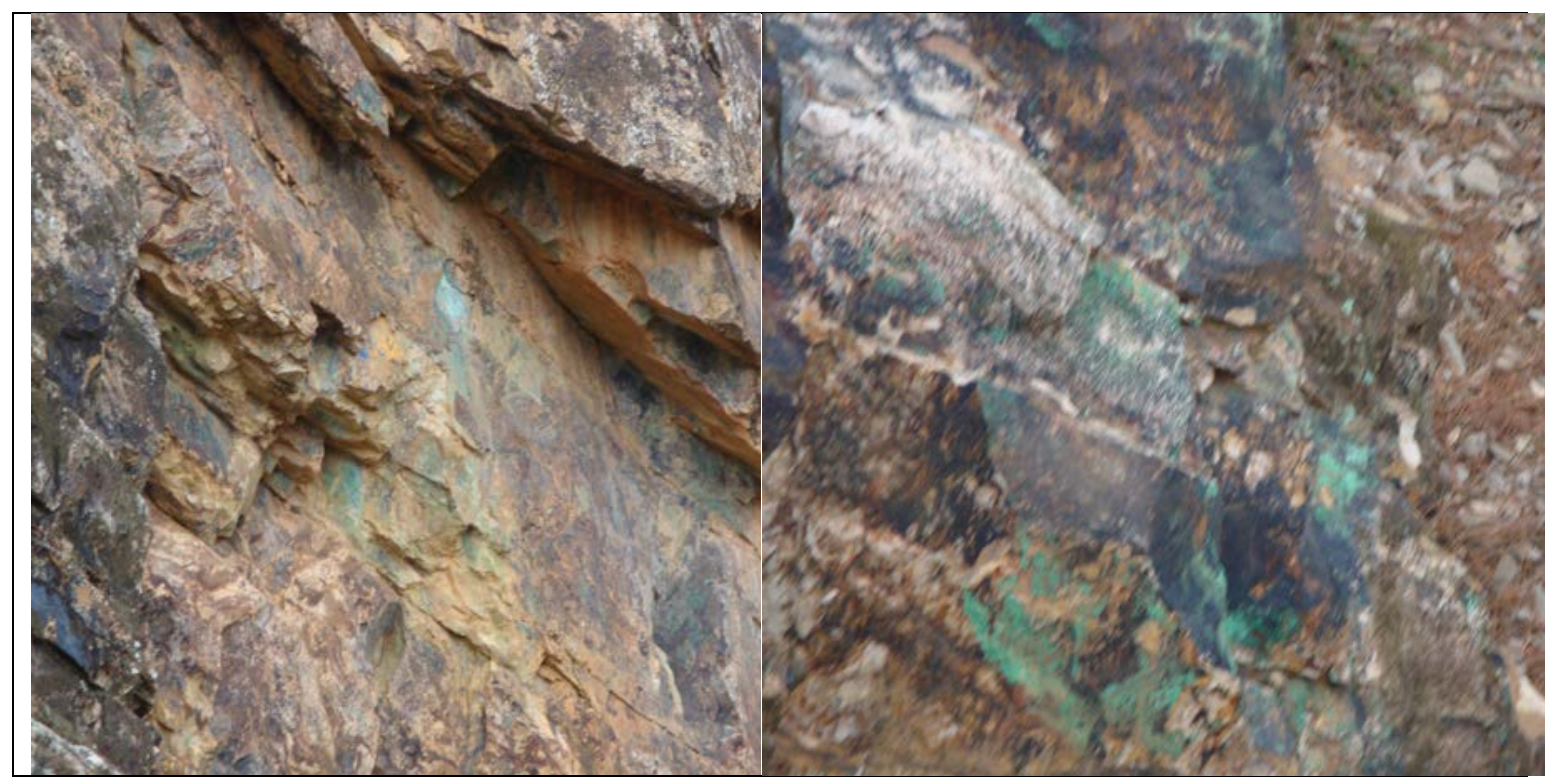

FOTOGRAFIES 10 i 11 Dos aspectes de les mineralitzacions de coure. Desembre del 2011

\subsection{Parada 9. Mines de Montalbán. Minas de coure de Pavías - 2, (terme municipal de Pavíes I Pavíes, comarca de l'Alt Palància. (Full 640).}

Després de realitzar la parada anterior, cal continuar uns $0^{\prime} 5 \mathrm{Km}$ pel camí de terra. Posteriorment, caldrà pujar per un corriol cap a les antigues mines de coure de Montalbán. En arribar-hi, farem la darrera aturada d'aquest itinerari. Així, haurem fet un recorregut aproximat de $1 \mathrm{Km}$, des de la parada anterior.

En aquest recorregut, haurem trobat afloraments dels materials esmentats a l'aturada anterior. Així, haurem vist materials del Triàsic i del Paleozoic. Per d'altra banda, com en tot el recorregut, estem situats dintre del Sistema Ibèric. 
Com a la parada anterior, es tracta d'una interessant mineralització cuprífera associada a redbed. Aquesta es troba entre els gresos del Buntsandstem, en contacte per falla amb els materials paleozoics. entre els minerals presents es fan força pesos els carbonats, l'atzurita i la malaquita, com a la parada anterior (fotografia 12).

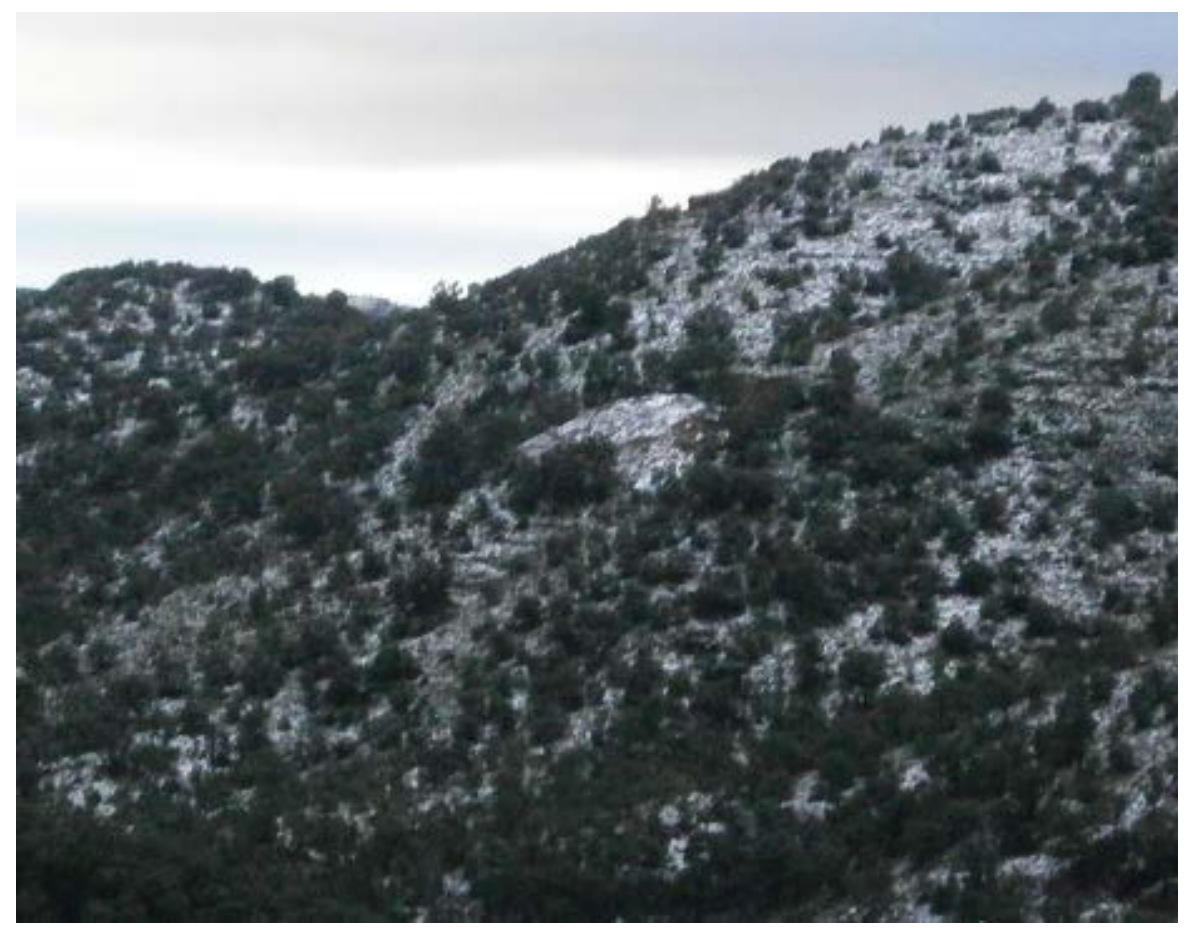

FOTOGRAFIA 12. Indret on es troba la Mina de Coure de Montalbán Novembre del 2013

En aquest indret finalitza l'itinerari

\section{Bibliografia}

GUIMERÀ, J. et altri /1992).- Geologia (II), Història Natural dels Països Catalans, Vol.2, 547 pag. Enciclopèdia Catalana, S,A,, Barcelona

I.G.M.E (1974).- Mapa Geológico de España, a escala 1:50.000, 2a Sèrie. Hoja i memória ${ }^{\circ}$ 640 (Segorbe). Inst. Geol Minero de España. Minist. Indústria. Madrid

I.G.M.E (1974).- Mapa Geológico de España, a escala 1:50.000, 2a Serie. Hoja i memória no 668 (Sagunto). Inst. Geol Minero de España. Minist. Indústria. Madrid 
LOPEZ, J. i ARCHE, A. (1986).- Estratigrafia del Permico y Triàsico, en facies Buntsandsteim y Muschelkalk, en el sector Sudeste de la rama castellana de la Cordillera Ibérica (Provincias de Cuenca y de Valéncia). Estudios Geológicos, nº. 42, pp. 123-143. Madrid

MATA-PERELLÓ, J.M. (1984).- Els Minerals del País Valencià, Col-lecció Informe, nº 6, 546 pàgines. Manresa

MATA-PERELLÓ, J.M. (1996).-Recerca Geològica i Mineralògica per I’Alt Palància i per la Plana Baixa: des de Sot de Ferrer a Soneixer, Xóvar, Eslida i a Betxí. Revista XARAGALL, Sèrie B. $n^{\circ} 30,10$ pag. Manresa

MATA-PERELLÓ, J.M. (2003).-Recerca Geològica i Mineralògica per les comarques de I'Alt Palància, el Camp de Morvedre i per la Plana Baixa: des de Sot de Ferrer a Assuévar, Soneixer, Xóvar, Eslida, Artana i a Betxí. 12 pàgines. Inèdit. Manresa

MATA-PERELLÓ, J.M. (2004).- Recerca geològica i mineralògica per I'Alt Palància, el Camp de Morvedre i per la Plana Baixa: de Sot de Ferrer i Algar de Palància a la Fondeguilla, Xóvar, Eslida i Artana. Inèdit, 12 pag. Manresa

MATA-PERELLÓ, J.M. i VILALTELLA FARRÀS, J. (2010).- Recerca geològica i mineralògica per I'Alt Palància, el Camp de Morvedre i per la Plana Baixa: de Sot de Ferrer i Algar de Palància a la Fondeguilla, Xóvar i a Eslida. Inèdit. 12 pàgines. Manresa

MATA-PERELLÓ, J.M. i VILALTELLA FARRÀS, J. (2013).- Recerca geològica i mineralògica per les comarques de l'Alt Palància, del Camp de Morvedre i per la Plana Baixa: des de Sot de Ferrer i Algar de Palància a Soneìxer / Soneja, Xóvar / Chovar i a Eslida. Inèdit- 16 pàgines. Manresa

MATA-PERELLÓ, J.M. i SANZ BALAGUER, J. (1988).- Guia de determinació de Minerals, adaptada als Països Catalans. Parcir, Edicions Selectes, 207 pàgines. Manresa

MATA-PERELLÓ, J.M. i VILALTELLA FARRÀS, J. (2013).- Recerca geològica i mineralògica per les comarques de l'Alt Palància, del Camp de Morvedre i per la Plana Baixa: des de Sot de Ferrer i Algar de Palància a Sonèixer / Soneja, Xóvar / Chovar i a Eslida. Inèdit- 16 pàgines. Manresa

MATA-PERELLÓ, J.M. et altri (2012).- El patrimonio minero de la comarca del Alto Palància (Castellón, Comunidad Valenciana, Sistema Ibérico). Actas del XIII Congreso internacional sobre patrimonio geològico y minero, pp. $743-752$. Manresa

RIBA, O. et altri (1976).- Geografia Física dels Països Catalans. Edit. Ketres, 254 pàgines. Barcelona

TRITLLA i CAMBRA,J. (1994).- Geologia y metalogenia de las mineralizaciones de Ba-Hg de la Serra de I'Espadà (Provincia de Castellón). Universitat Autònoma de Barcelona, 235 pàgines. Bellaterra 